\title{
Differences in the Ways Sympathetic Neurons and Endocrine Cells Process, Store, and Secrete Exogenous Neuropeptides and Peptide-Processing Enzymes
}

\author{
Ruth Marx, ${ }^{1}$ Rajaâ El Meskini, ${ }^{1}$ David C. Johns, ${ }^{3}$ and Richard E. Mains ${ }^{1,2}$ \\ Departments of ${ }^{1}$ Neuroscience, ${ }^{2}$ Physiology, and ${ }^{3}$ Medicine, The Johns Hopkins University School of Medicine, \\ Baltimore, Maryland 21205-2185
}

\begin{abstract}
Most neurons store peptides in large dense core vesicles (LDCVs) and release the neuropeptides in a regulated manner. Although LDCVs have been studied in endocrine cells, less is known about these storage organelles in neurons. In this study we use the endogenous peptide NPY (neuropeptide Y) and the endogenous peptide-processing enzyme PAM (peptidylglycine $\alpha$-amidating monooxygenase) as tools to study the peptidergic system in cultured neurons from the superior cervical ganglion (SCG). Once mature, SCG neurons devote as much of their biosynthetic capabilities to neurotransmitter production as endocrine cells devote to hormone production. Unlike pituitary and atrium, SCG neurons cleave almost all of the bifunctional PAM protein they produce into soluble monofunctional enzymes. Very little PAM or NPY is secreted under basal condi-
\end{abstract}

Nearly all neurons secrete bioactive peptides along with conventional neurotransmitters (Jahn and Sudhof, 1993; Calakos and Scheller, 1996; Klumperman et al., 1996; Xu et al., 1996; Dannies, 1999; Mains and Eipper, 1999; Polgar et al., 1999). At least two types of secretory organelles, small synaptic vesicles (SSV) and large dense-core vesicles (LDCVs), are involved in the secretion process. SSVs originate from the endosomal compartment, contain classical neurotransmitters, and recycle locally in nerve terminals. LDCVs emerge from the trans-Golgi network (TGN) and are transported down the axon to release soluble contents, including proteins and peptides acting as neuromodulators and hormones. Although both SSVs and LDCVs undergo regulated secretion, there are significant differences between these two processes. Recent work revealed some of the molecular mechanisms underlying SSV biogenesis, secretion, and recycling; much less is known about the biogenesis and secretion from LDCVs in neurons (Calakos and Scheller, 1996; Mains and Eipper, 1999).

The diversity and low levels of neuropeptides make them difficult to study, so we used primary neurons in culture and a processing enzyme common to many of the neuropeptides (peptidylglycine $\alpha$-amidating monooxygenase; PAM) to facilitate these studies. Neuropeptide Y (NPY) is the most abundant

\footnotetext{
Received May 14, 1999; revised June 23, 1999; accepted July 21, 1999.

This work was supported by National Institutes of Health Grant DA-00266.We thank Betty Eipper, Angela Bruzzaniti, and Chenie Bell-Parikh for many constructive scientific suggestions and for comments on this manuscript. We also thank Lixian Jin and Marie Bell for technical support and Dee Andryszak for administrative help.

Correspondence should be addressed to Dr. Richard E. Mains, Department of Neuroscience, The Johns Hopkins University School of Medicine, 725 North Wolfe Street, Baltimore, MD 21205-2185.

Copyright (C) 1999 Society for Neuroscience $\quad 0270-6474 / 99 / 198300-12 \$ 05.00 / 0$
}

tions, and the addition of secretagogue dramatically stimulates the secretion of PAM and NPY to a similar extent. Although endocrine cells typically package "foreign" secretory products together with endogenous products, pro-opiomelanocortinand PAM-derived products encoded by adenovirus in large part were excluded from the LDCVs of SCG neurons. When expressed in corticotrope tumor cells and primary anterior pituitary cultures, the same virally encoded products were metabolized normally. The differences that were observed could reflect differences in the properties of neuronal and endocrine peptidergic systems or differences in the ability of neurons and endocrine cells to express viral transcripts.

Key words: superior cervical ganglion; PAM; ACTH; neuropeptide Y; PC1; PC2; regulated secretion peptide in the brain and in the superior cervical ganglion (SCG) (McGreevey and Seeley, 1999; Tajti et al., 1999). Most SCG neurons are catecholaminergic, and two-thirds of the neurons coexpress norepinephrine and NPY plus smaller amounts of enkephalin, somatostatin, galanin, pituitary adenylate cyclaseactivating peptide, vasoactive intestinal peptide, and substance $\mathrm{P}$ (Marek and Mains, 1989; Freidin et al., 1993; Hyatt-Sachs et al., 1993; Hall and MacPhedran, 1995; May and Braas, 1995a; Mehler et al., 1995; Shadiack et al., 1995; Brandenburg et al., 1997). NPY is a highly conserved 36 residue amidated peptide with pre- and postsynaptic actions (Tatemoto et al., 1982; Lundberg, 1996). Like most neuropeptides, NPY is synthesized as a larger precursor molecule; pro-NPY requires cleavage by prohormone convertase 2 (PC2) plus the actions of carboxypeptidase E (CPE) and PAM to generate mature NPY (Paquet et al., 1996). The NPY biosynthetic rate in culture reaches the rate for adult SCG neurons in vivo (Marek and Mains, 1989). SCG neurons devote approximately one-fourth of all of the tyrosine they metabolize to the production of catecholamines, comparable to the fraction of protein synthesis devoted to pro-opiomelanocortin (POMC) by pituitary melanotropes (Mains and Patterson, 1973; Mains and Eipper, 1979).

PAM is the only enzyme known to $\alpha$-amidate peptides (Eipper et al., 1993); because many peptides produced by SCG neurons are amidated, PAM serves as a useful tool to study the peptidergic system. Peptide $\alpha$-amidation is a two-step reaction catalyzed by the two distinct catalytic domains within PAM, peptidylglycine- $\alpha$-hydroxylating monooxygenase (PHM) and peptidyl- $\alpha$ hydroxyglycine $\alpha$-amidating lyase (PAL). PAM is an integral membrane protein expressed in a wide variety of cell types, including endocrine, glial, and endothelial cells, and in many neurons. In 
peripheral and central neurons PAM is localized to LDCVs in axons and nerve terminals (Oyarce and Eipper, 1993; Quatacker et al., 1993).

This study focuses on the processing, storage, and secretion of PAM in neurons that develop both axons and dendrites in culture. Differences in the peptidergic system between neuronal (extremely polarized) and endocrine (not polarized) cells are addressed. NPY was used as a marker for the neuronal LDCVs, and, as anticipated for a neuropeptide that resides in the granules, NPY secretion was increased dramatically on stimulation. To understand more about the peptidergic system in neurons, we used recombinant adenoviruses to overexpress POMC and PAM in the neurons. The adenovirus system has proven to be a very efficient tool for the delivery of foreign genes to many different cell types (Moriyoshi et al., 1996; Paquet et al., 1996; Slack and Miller, 1996; Slack et al., 1996; Marx and Mains, 1997; Johns et al., 1999).

\section{MATERIALS AND METHODS}

Preparation of SCG and pituitary cultures. SCG cultures were prepared as previously described (Paquet et al., 1996). Briefly, SCGs were dissected from 2-d-old neonatal rat pups (Sprague Dawley rats purchased from Charles River, Wilmington, MA) and dissociated for $20 \mathrm{~min}$ at $37^{\circ} \mathrm{C}$ in DMEM-air medium containing $4 \mathrm{mg} / \mathrm{ml}$ collagenase, $1 \mathrm{mg} / \mathrm{ml}$ hyaluronidase, $0.1 \mathrm{U} / \mathrm{ml}$ benzonase, and $10 \mathrm{mg} / \mathrm{ml}$ fatty acid-free bovine serum albumin (BSA), followed by a $15 \mathrm{~min}$ dissociation in medium containing $3 \mathrm{mg} / \mathrm{ml}$ trypsin (T-0646, Sigma, St. Louis, MO). The dissociated cells were plated onto collagen-coated dishes (Bornstein, 1958) in DMEM/ F-12 supplemented with $10 \%$ FBS and $200 \mathrm{ng} / \mathrm{ml}$ nerve growth factor (NGF; kindly provided by Dr. David Ginty, Johns Hopkins University) for the first $24 \mathrm{hr}$ and then maintained in DMEM/F-12, 10\% FBS, 200 $\mathrm{ng} / \mathrm{ml}$ nerve growth factor, and $10 \mu \mathrm{M}$ cytosine arabinoside. A similar method was used to prepare anterior pituitary cultures from adult male rats (Oyarce and Eipper, 1995). Mouse corticotrope AtT-20 cells were grown in DMEM/F-12 supplemented with $10 \%$ Fetal Clone I (HyClone, Logan, UT) and 10\% Nu-Serum (Collaborative Research, Bedford, MA), as described previously (Milgram et al., 1994).

Recombinant adenovirus (Ad): construction and use of AdPOMC and AdPAM-1 and viral infections. Mouse POMC (nucleotides 1-920) (Uhler and Herbert, 1983) and rat PAM-1 (nucleotides 293-3245, as used for transfecting PAM-1 stable lines) (Milgram et al., 1992) cDNAs were subcloned into the virus shuttle vector. HEK293-CRE8 cells were cotransfected with the shuttle vector (AdLox) and purified $\psi 5$ adenoviral DNA to create the recombinant viruses (Hardy et al., 1997). The 2-weekold SCG cultures, 3-d-old anterior pituitary cultures, and mouse corticotrope AtT-20 cells were infected via a 1:5000 dilution of the viral stock $\left(1 \times 10^{7} \mathrm{pfu} / \mathrm{ml}\right)$ of recombinant adenovirus encoding POMC (AdPOMC) or PAM-1 (AdPAM-1). The next day the medium was replaced; $24 \mathrm{hr}$ later the infected cells were used for immunostaining, secretion, and biosynthetic labeling experiments.

Biosynthetic labeling and immunoprecipitations. Metabolic labeling of the cells was performed as described previously (Milgram et al., 1994; Marx and Mains, 1997). Cultures were incubated in Complete serum-free medium (CSFM: DMEM/F12 with $2 \mathrm{mg} / \mathrm{ml}$ fatty acid-free BSA, $1 \mu \mathrm{g} / \mathrm{ml}$ insulin, and $0.1 \mu \mathrm{g} / \mathrm{ml}$ transferrin) lacking methionine for $5 \mathrm{~min}$ and then labeled for $30 \mathrm{~min}$ with $210-300 \mu \mathrm{Ci}$ of $\left[{ }^{35} \mathrm{~S}\right]$ methionine (Amersham, Arlington Heights, IL) in $300 \mu \mathrm{l}$ of $\mathrm{Met}^{-}$medium. Cells either were harvested immediately (pulse) or were incubated further in CSFM (114 $\mu \mathrm{M}$ methionine) for different times. Spent media were centrifuged to remove debris, and a mixture of protease inhibitors was added (Milgram et al., 1992). Cells were extracted in $5 \mathrm{M}$ acetic acid/BSA and lyophilized overnight. Cell extracts were resuspended in $50 \mu \mathrm{M}$ Na-phosphate, $1 \%$ Triton X-100. Aliquots of the cell extract or spent media were incubated with $10 \mu \mathrm{l}$ of rabbit polyclonal antiserum to NPY (JH3) or ACTH(1-17) (JH93) for $4 \mathrm{hr}$ at $4^{\circ} \mathrm{C}$ (Milgram et al., 1996a). Immune complexes were collected after being shaken with $20 \mu \mathrm{l}$ of protein A-Sepharose beads (Sigma) in $50 \mu \mathrm{M}$ Na-phosphate, $1 \%$ Triton X-100, $\mathrm{pH} 7.5$, for $1 \mathrm{hr}$ and then were analyzed by SDS-PAGE. Gels were fixed in $30 \%$ isopropanol/ $10 \%$ acetic acid and prepared for fluorography by incubation in Amplify (Amersham).

Immunofluorescent staining. The localization of PAM, NPY, TGN38, MAP2, tau, and POMC in the SCG neurons was detected by using indirect immunofluorescence (Milgram et al., 1997). Cells were fixed by using $4 \%$ paraformaldehyde in PBS, followed by permeabilization with $0.075 \%$ Triton $\mathrm{X}-100$, or they were fixed by using $-20^{\circ} \mathrm{C}$ methanol (for TGN38 staining); blocking was performed with $2 \mathrm{mg} / \mathrm{ml}$ BSA in PBS for $1 \mathrm{hr}$. Monoclonal antibodies against MAP2 (clone HM-2, Sigma) and tau (clone tau-1, Boehringer Mannheim, Indianapolis, IN) and rabbit polyclonal antisera against PAM (JH629), NPY (JH3), TGN38 (JH1481), and POMC (JH44; JH93; Georgie; monoclonal from Novocastra Labs UK) were used at a dilution of 1:1000 or more for $2 \mathrm{hr}$ at room temperature (Schnabel et al., 1989; Milgram et al., 1996b, 1997). Antigen-antibody complexes were visualized by using FITC-conjugated goat anti-rabbit IgG (Caltag, San Francisco, CA) and Cy3-conjugated donkey anti-mouse IgG (Jackson ImmunoResearch, West Grove, PA). Samples were viewed with a Zeiss Axioskop microscope (Carl Zeiss, Thornwood, NY) and photographed with a Micromax CCD camera (Princeton Instruments, Princeton, NJ).

Secretion experiments and analysis. Noninfected SCG neurons and neurons infected with either AdPOMC or AdPAM-1 were fed with CSFM with $200 \mathrm{ng} / \mathrm{ml}$ NGF overnight. Wells initially were rinsed (Ratovitski et al., 1999) for three 30 min periods in CSFM with $200 \mathrm{ng} / \mathrm{ml}$ NGF. The experiment was begun with two successive $2 \mathrm{hr}$ basal collections that used CSFM with $200 \mathrm{ng} / \mathrm{ml} \mathrm{NGF}$, followed by one $2 \mathrm{hr}$ period of stimulated secretion that used CSFM with $200 \mathrm{ng} / \mathrm{ml} \mathrm{NGF}$ and $1 \mathrm{~mm}$ $\mathrm{BaCl}_{2}$ (May et al., 1998; Ratovitski et al., 1999). The collected medium was centrifuged to remove the few nonadherent cells, and protease inhibitors were added. Cells for PHM and PAL activity analyses or

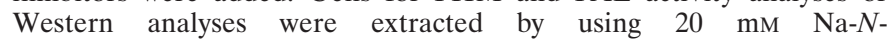
Tris[hydroxymethyl]methyl-2-aminoethanesulfonic acid (TES), $10 \mathrm{~mm}$ mannitol, and $1 \%$ Triton $\mathrm{X}-100, \mathrm{pH} 7.4$ (TMT), to which protease inhibitors were added. Cell extracts were frozen and thawed three times and centrifuged for $5 \mathrm{~min}$ to remove cell debris. For ACTH and NPY radioimmunoassay (RIA), the cells were extracted in $5 \mathrm{~m}$ acetic acid/ BSA, lyophilized, and resuspended in RIA buffer with protease inhibitors. Samples were stored at $-80^{\circ} \mathrm{C}$ until assay. Secretion experiments with AtT-20 cells were performed in a similar way, except that CSFM without NGF was used for the medium collections, and each collection was for $30 \mathrm{~min}$. RIAs were performed by using spent medium collections or cell extracts, antibody to NPY (JH3, 1:40,000) and ${ }^{125}$ I-NPY (Amersham) (Marek and Mains, 1989); antibody to ACTH (Kathy, 1:20,000) and ${ }^{125} \mathrm{I}$-ACTH (Amersham) or ${ }^{125}$ I-CLIP (iodinated with Iodobeads) (Eipper et al., 1983; Schnabel et al., 1989); or antibody to all POMC derivatives (Bertha, 1:30,000) and ${ }^{125}$ I-ACTH (1-39, NEN Life Science Products) (Mains and Eipper, 1976). Antiserum Kathy only recognizes POMC products in which the COOH-terminal end of ACTH(1-39) is exposed (Schnabel et al., 1989), and antibody Bertha recognizes the intact precursor as well as the processed products (Mains and Eipper, 1976). Data were analyzed with an Excel program that used the logit-log transformation (Davis et al., 1980; Marschner et al., 1980).

Protein analyses. Cell extracts and medium collections were subjected to $12 \%$ SDS-PAGE and Western blot analysis that used a PHM antiserum (JH1761, 1:1000), a PAL antiserum (JH471, 1:1000), an Exon A antiserum (JH629, 1:1000), or monoclonal antibody to PAM-CD (6E6, 1:20), followed by enhanced chemiluminescence detection (Amersham) (Milgram et al., 1996b, 1997). Enzyme assays were performed as described previously; samples (spent medium and cell extract) were assayed in duplicate (Milgram et al., 1992). PHM and PAL reactions were performed in a final volume of $40 \mu \mathrm{l}$ for $2 \mathrm{hr}$.

\section{RESULTS}

\section{PAM is found in soma and axons of the SCG neurons}

We first tested whether endogenous PAM levels are detectable in the SCG neurons in culture, using indirect double immunofluorescence staining. Similar punctate staining is observed by using either antibodies to PAM (Fig. $1 A$ ) or to neuropeptide Y (NPY) (Fig. 1C); simultaneous localization with the axonal marker tau identifies many of the PAM-NPY-stained processes as axons. PAM staining is relatively more intense in cell bodies than NPY is. As additional markers, we used antibodies to microtubuleassociated protein 2 (MAP2), a neuronal-specific marker for dendrites, and an antibody to a TGN marker protein (TGN38). TGN38 was localized to the perinuclear region of the neuron, while no TGN38 staining in processes was observed (Fig. 1B). 
A.
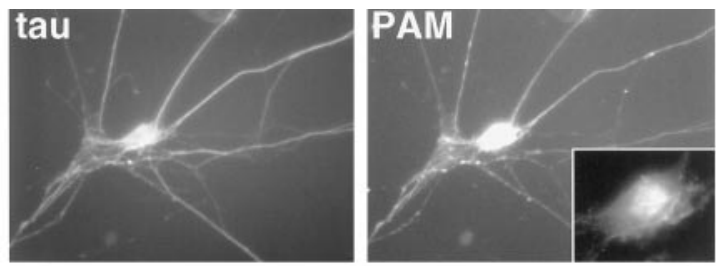

B.

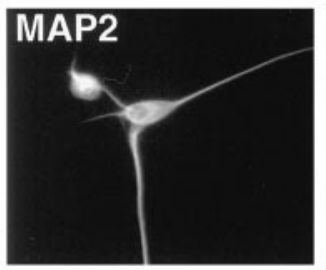

C.
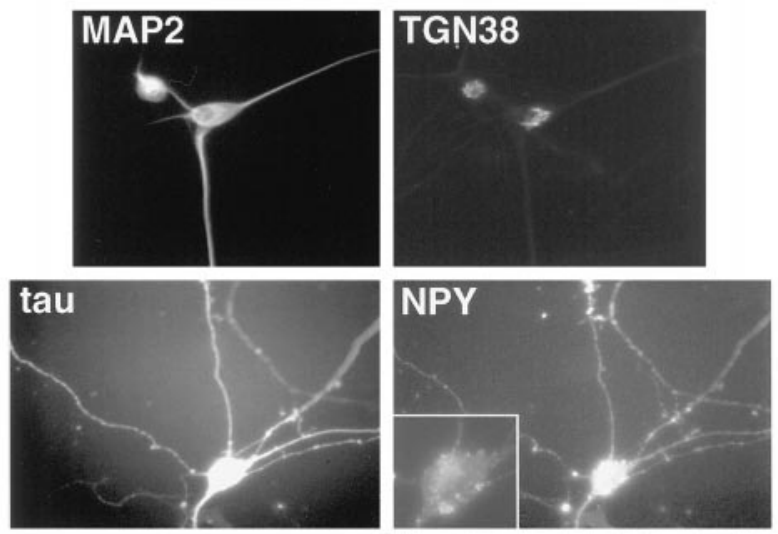

D.
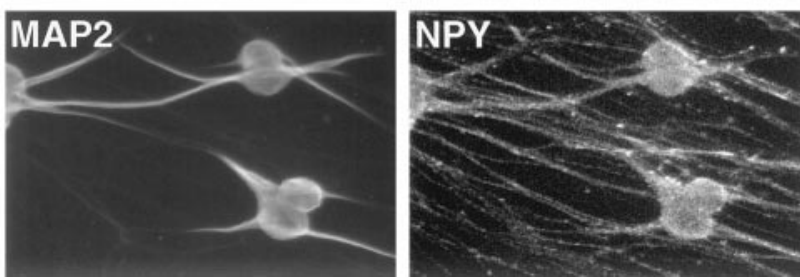

Figure 1. Localization of PAM, NPY, and TGN38 in cultured SCG neurons. Primary SCG cultures were fixed and permeabilized. Cells were incubated simultaneously with monoclonal antibody to tau and either polyclonal antibody to PAM $(A)$ or polyclonal antibody to NPY $(C)$. Cells were incubated simultaneously with monoclonal antibody to MAP2 and either polyclonal antibody to TGN38 $(B)$ or polyclonal antibody to NPY $(D)$. The higher power insets in $A$ and $C$ were adjusted to avoid overexposing the cell body.

The pattern of PAM staining within the cell bodies resembles TGN38 staining. Antibody to MAP2 stains cell bodies and processes, and those processes were designated thereby as dendrites (Fig. 1B,D). Punctate NPY staining of cell bodies and processes was observed (Fig. 1D). Many of the NPY-positive processes showed no MAP2 staining, which indicated the localization of the majority of NPY in axons.

\section{The level of PAM expression in SCG is as high as anterior pituitary}

To evaluate the level of PAM expression in SCG neurons and to select the optimal time for studying PAM processing, storage, and secretion in the SCG cultures, we performed Northern analyses, using total RNA from SCG, brain, and adrenal (Fig. 2). PAM mRNA is expressed at higher levels in the SCG than in the whole brain. The expression of PAM mRNA increases postnatally to adulthood in both the brain and in the SCG, similar to the expression pattern of NPY mRNA in the SCG (Marek and Mains, 1989). The specific activity of the rate-limiting initial enzyme in PAM, the monooxygenase, was higher in SCG than in adult anterior pituitary or heart atrium $(10 \mathrm{nmol} / \mathrm{mg}$ protein per hour in SCG; 3-5 nmol/mg protein per hour in anterior pituitary and atrium) (Maltese and Eipper, 1992; Mueller et al., 1993; Oyarce and Eipper, 1995). Thus we used 2-week-old SCG cultures for this work, because then PAM and NPY levels approximate their adult values.

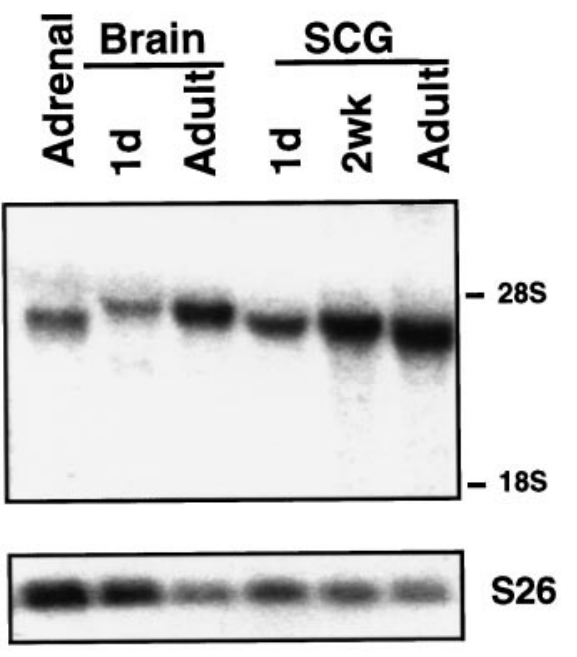

Figure 2. Northern blot analysis of total RNA samples. Tissues dissected from the animal were placed into RNA STAT-60 reagent (Tel-Test, Friendswood, TX). Total RNA was extracted according to the manufacturer's instructions. Then $10 \mu \mathrm{g}$ of total RNA from each sample was fractionated on a $1 \%$ agarose gel, and Northern blot analyses were performed as described before (Paquet et al., 1996), using samples from adult adrenal; neonatal and adult brain; and neonatal, 2-week-old, and adult SCG. The blot was probed with PAM cDNA (top) and S26 ribosomal protein cDNA (bottom).

\section{PAM is stored in highly stimulatable granules in cultured SCG neurons}

To determine whether PAM proteins are stored in the LDCVs, we studied the stimulation of secretion of both PHM and PAL enzyme activities from the SCG neurons and compared it with the secretion of NPY, which is known to be stored and secreted through the LDCVs (May et al., 1995b). Stimulation of secretion experiments included two basal collections ( $2 \mathrm{hr}$ each), followed by the addition of a medium containing barium $\left(\mathrm{Ba}^{2+}\right)$ to activate secretion (May et al., 1998; Johns et al., 1999); all results were normalized for the length of time of secretion. Basal NPY secretion was very low compared to NPY cell content (50-100 fmol/ culture per hour), $<1 \%$ of the cell content of NPY per hour. On stimulation, NPY secretion increased 20-fold (Fig. 3A). NPY was stored very efficiently in the LDCVs, as indicated by the low rate of basal secretion, and the release of NPY from the neurons increased dramatically on stimulation.

Levels of PHM and PAL activities were tested in the same basal and stimulated medium samples. For both PHM and PAL activities the SCG neurons yielded a 20 -fold stimulation of secretion (Fig. 3B,C). The extents of stimulation of secretion of NPY, PHM, and PAL activities are in excellent agreement with each other.

\section{PAM is processed to soluble, secretable PHM and PAL in cultured SCG neurons}

Western blot analysis of extracts from primary SCG neurons shows the expression of intact PAM-1 and its processed products: PAL-TMD-CD, PHM, PAL, and TMD-CD (Fig. 4A). Western blot analysis of cultured SCG neuron cell extracts that use an antibody to the PHM domain indicates the expression of PAM-1 but no significant amount of PAM-2 (which is smaller and lacks the noncatalytic domain Exon A; data not shown). Thus, the main PAM isoform expressed in the SCG primary neuronal cultures is PAM-1, a type 1 membrane protein. Two lysine-lysine 
A. NPY

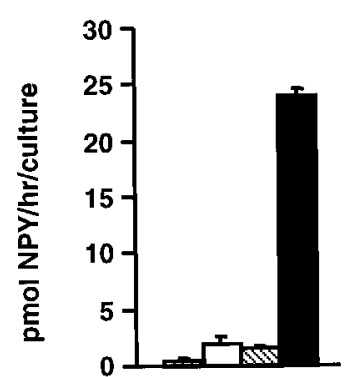

B.

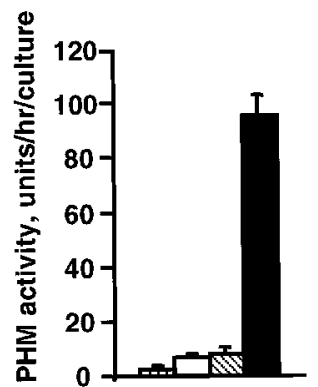

c.

PAL

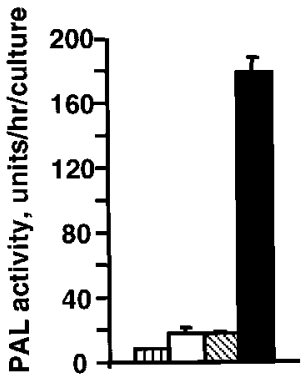

⿴囗十.n.

$\square$ 1st basal

Q 2nd basal

stimulated

Figure 3. Secretion of NPY immunoreactivity and PHM and PAL enzyme activities from cultured SCG neurons. Medium was collected overnight and after two consecutive $2 \mathrm{hr}$ periods of basal secretion, followed by $2 \mathrm{hr}$ of stimulated secretion $\left(1 \mathrm{mM} \mathrm{BaCl}_{2}\right)$. $A$, The levels of NPY were determined in all medium samples by RIA. PHM $(B)$ and PAL $(C)$ enzyme activities were measured in duplicate samples of the collected medium samples. Data are the mean \pm SD for four determinations. Similar results were obtained in four independent experiments. All experiments were done with 15- to 18-d-old cultures. o.n., Overnight.

\section{A. Cell extract}

$\mathrm{kDa}$

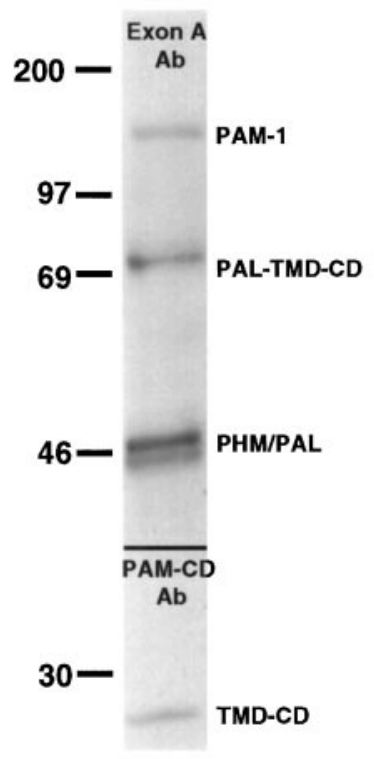

B. Stimulated Medium

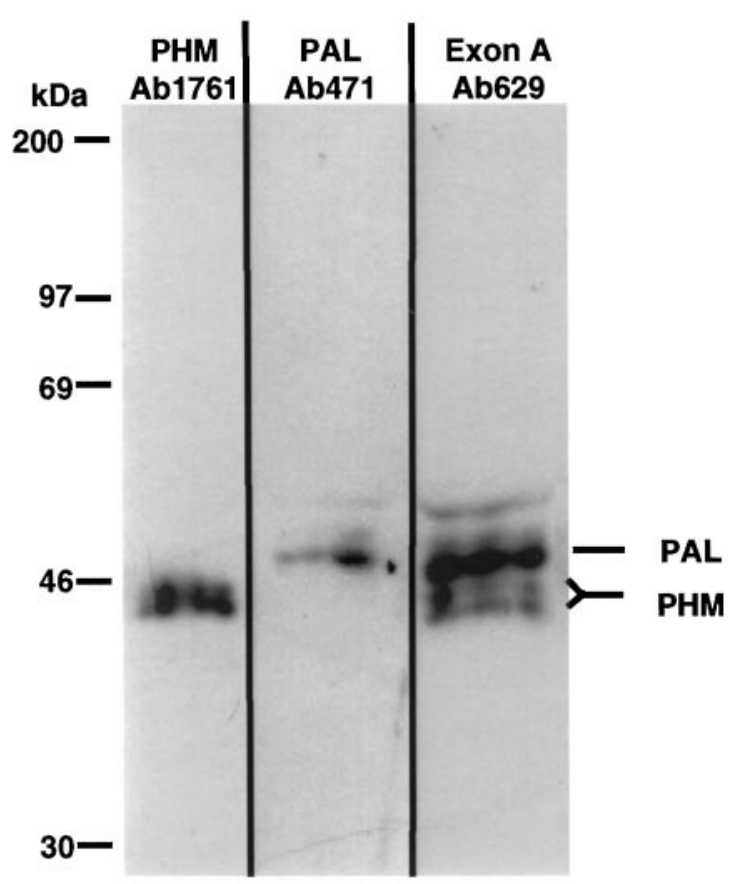

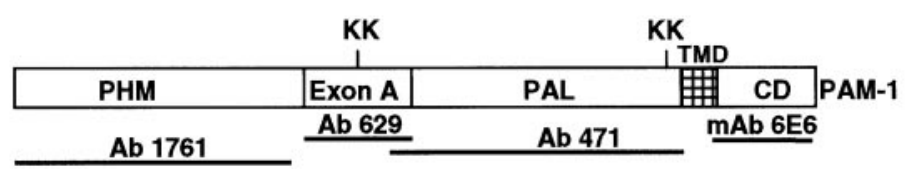

Figure 4. PAM expression in the SCG. A, Western blot analysis of PAM proteins in primary SCG culture. Cell extract prepared in TES/mannitol/Triton X-100 (TMT) was subjected to Western blot analysis with an antibody to Exon A (JH629, top of the gel) and an antibody to PAM-CD (mAb 6E6, bottom of the gel). $B$, Medium samples collected after $\mathrm{BaCl}_{2}$ stimulation were visualized by using antibodies to PHM (JH1761), PAL (JH471), and Exon A (JH629). Similar results were obtained in two independent experiments. The schematic diagram (bottom of the figure) of PAM-1 indicates the different domains and the antibodies that were used.

(KK) sites found within the PAM-1 protein (within Exon A and in the $\mathrm{COOH}$-terminal of PAL) are likely to be used specifically to give rise to the different proteins detected on the Western blot (Eipper et al., 1993).

Secretion of PHM and PAL activities from the neurons is dependent on cleavage events that occur in the TGN and in the granules, generating soluble proteins from membrane PAM. To study the processing of PAM further, we have characterized secreted PAM fragments, using Western blot analysis of stimulated medium samples (Fig. 4B). Separate soluble PHM and PAL proteins are released to the medium, although no bifunctional PAM is secreted (e.g., PHM-Exon A-PAL from PAM-1, $M_{\mathrm{r}}=$ 

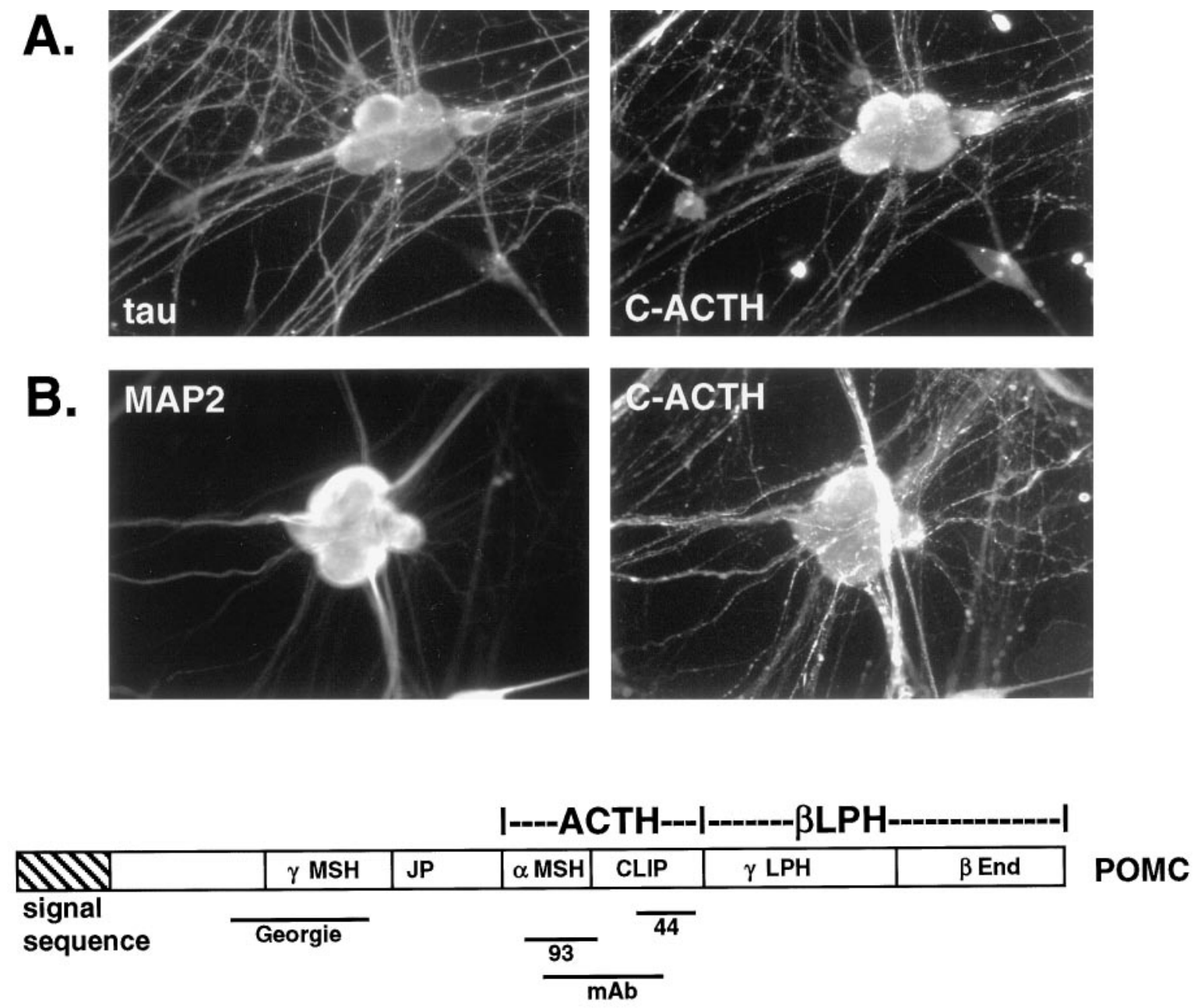

\begin{tabular}{rl|l|l|l|}
\hline & MSH & JP & $\alpha M S H$ & CLIP ABI \\
& $\alpha$ MSH & CLIP ACTH \\
\hline
\end{tabular}

Figure 5. Localization of POMC-processed products in AdPOMC-infected SCG cultures. Primary SCG cultures were infected with AdPOMC virus, fixed, and permeabilized. Cells were incubated simultaneously with polyclonal antibody to C-ACTH and either monoclonal antibody to tau $(A)$ or monoclonal antibody to MAP2 $(B)$. Shown is the schematic diagram of the POMC precursor molecule and the processed products recognized by the C-ACTH antibody.

$70-100 \mathrm{kDa}$ ) (Fig. 4B). Furthermore, the approximately 2:1 ratio between PAL/PHM secreted activity (see Fig. 2B,C) indicates good cleavage and secretion of the PAL fragment, because the PAL domain of PAM-1 is known to have a higher turnover number than the PHM domain (Eipper et al., 1993). PAM is cleaved extensively and stored efficiently in highly stimulatable granules in cultured SCG neurons.

\section{Subcellular distribution of exogenous POMC products in SCG neurons in culture}

So that the processing and sorting of proteins in neuronal LDCVs could be investigated, the POMC precursor molecule has been introduced into SCG neurons, using a recombinant adenovirus system (Fig. 5). Double immunofluorescent staining of infected SCG neurons has been performed with an antibody that recognizes the $\mathrm{COOH}$-terminal end of the $\mathrm{ACTH}$ while not detecting intact POMC (see schematic diagram, Fig. 5), along with antibodies to MAP2 (dendritic marker) or to tau (axonal marker). The staining reveals a distribution of ACTH in cell bodies and axons similar to tau staining (Fig. $5 A$ ) and distinct from MAP2 staining (Fig. 5B). The punctate ACTH staining and distribution resemble the pattern of PAM staining in the axons, which suggests some ACTH localization in LDCVs. Similar staining was seen with two other ACTH antisera with distinct specificities and with one antiserum to the N-terminal region of POMC.

\section{Secretion of exogenous POMC and endogenous NPY is different}

POMC-infected SCG neurons were tested for ACTH and NPY secretion to compare the secretion of the virally encoded products and the endogenous proteins. Secretion of immunoreactive ACTH was determined under both basal and stimulated conditions. The levels of ACTH (Fig. 6A) detected in the basal medium collection were at least 10 -fold lower than the levels of NPY (Fig. 6B). However, when expressed as a percentage of the cell content of peptide, ACTH basal secretion rates were higher than 


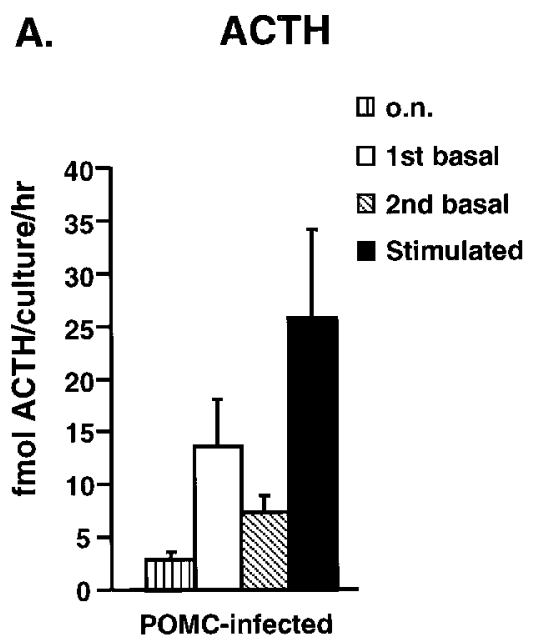

B. NPY

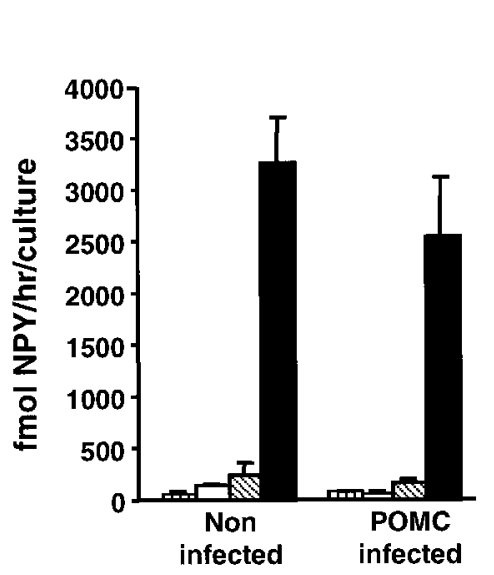

C.

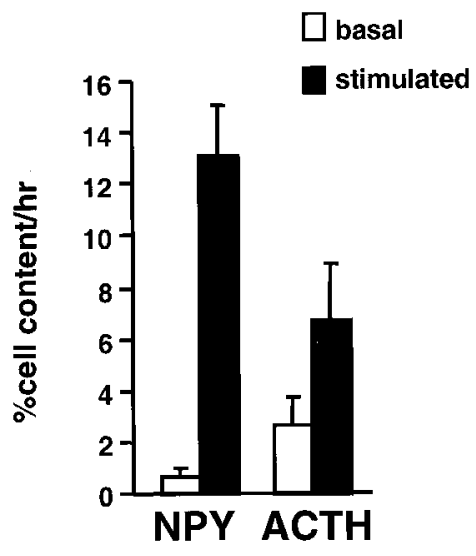

Figure 6. Secretion of ACTH immunoreactivity from POMC-infected cultured SCG neurons. Cultures either were infected with AdPOMC virus or were not infected. Then $48 \mathrm{hr}$ later the medium was analyzed from an overnight collection, and a secretion experiment was begun; after two consecutive

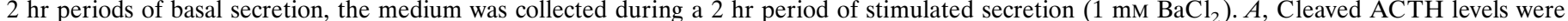
determined in all medium samples from POMC-infected cultures by RIA. $B$, The levels of NPY were determined in all medium samples, as described in Materials and Methods. $C$, Basal and stimulated levels of secretion of NPY and ACTH are expressed as a percentage of cell content. Data are the mean $\pm \mathrm{SD}$ for four determinations. Similar results were obtained in four independent experiments.

\section{A. Basal Secretion Rate}

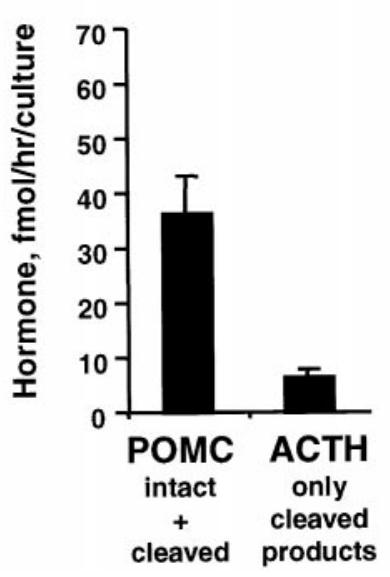

\section{B. Biosynthetic Labeling}

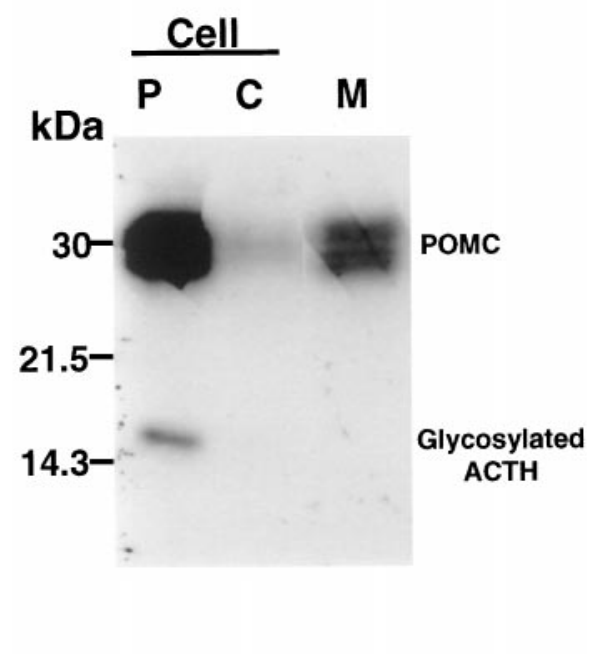

Figure 7. Secretion of ACTH and POMC from AdPOMC-infected SCG cultures. A, Basal secretion rates of immunoactive POMC (intact + cleaved), ACTH (only cleaved products), and NPY were determined in the same medium samples. Data are the mean \pm SD for four determinations. $B$, POMC-infected cells were labeled with $300 \mu \mathrm{Ci}$ of $\left[{ }^{35} \mathrm{~S}\right]$ methionine for $30 \mathrm{~min}$ and harvested $(P$, pulse) or chased $(C)$ in CSFM for $2 \mathrm{hr}$; spent medium $(M)$ was collected. Cells were extracted in $5 \mathrm{~N}$ acetic acid and lyophilized. Immunoprecipitations of the spent medium and cell extract were performed by using the antibody to the N-terminal of ACTH (JH93,) as described. Samples were fractionated by SDS-PAGE and visualized by fluorography. Similar results were obtained in four independent experiments.

NPY basal secretion rates (Fig. 6C). Unexpectedly, ACTH secretion showed only a twofold stimulation in response to $\mathrm{BaCl}_{2}$, much lower than the 10-fold stimulation seen for NPY from the same culture (Fig. 6A,B). When secretion from noninfected and infected neurons was compared, the NPY secretion was stimulated by 10 - to 20 -fold from infected neurons and noninfected cells (Fig. 6B).

In an effort to understand the limited stimulation of ACTH secretion, as well as the difference between the NPY and ACTH responses to secretagogue, we performed RIAs with two different ACTH antibodies; one antibody recognized only the exposed
$\mathrm{COOH}$-terminal of $\mathrm{ACTH}$, and the other recognized the intact POMC precursor and any of its derivatives that contain ACTH. The RIA data predicted that cleaved ACTH levels are only $\sim 15 \%$ of the total POMC levels (Fig. $7 A$ ), suggesting that cleavage of POMC is limited.

To compare better the synthesis and processing of POMC and pro-NPY, we performed biosynthetic labeling of POMC-infected SCG neurons. Precursors and products are isolated by immunoprecipitation, using antibodies to ACTH and NPY, and are fractionated by SDS-PAGE. On a molar basis the POMC precursor biosynthetic rate in infected neurons has ranged from a few 
A. Anterior Pituitary Endocrine Cells

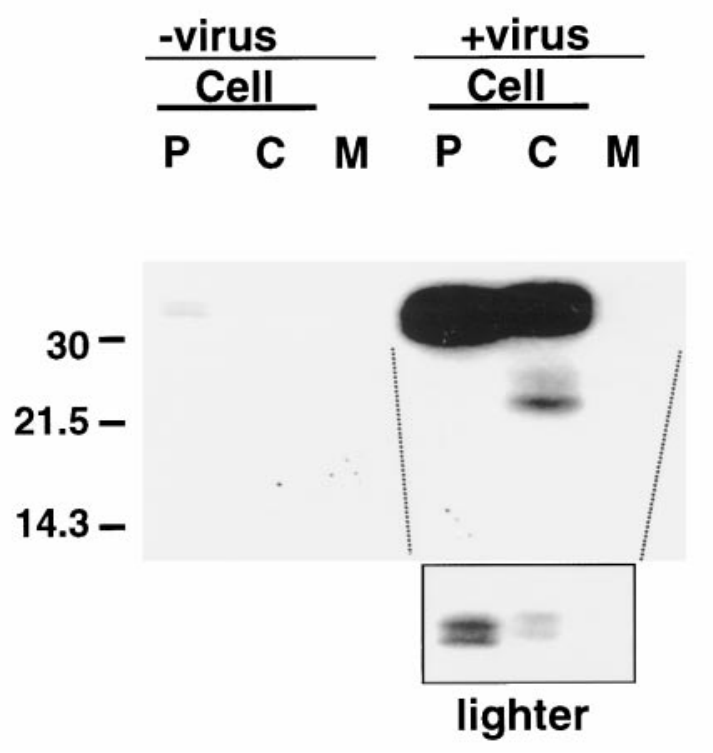

B. AtT-20 Cells

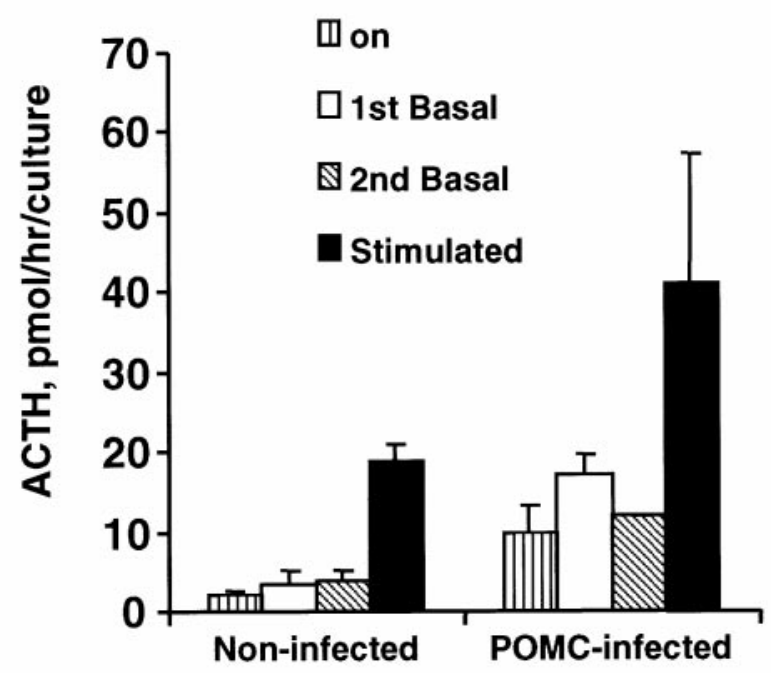

Figure 8. Secretion of ACTH immunoreactivity from POMC-infected pituitary cells. Primary anterior pituitary and AtT-20 cells either were infected with AdPOMC virus or were not infected and were analyzed after $48 \mathrm{hr}$. $A$, Anterior pituitary cultures were labeled and analyzed as in Figure $7 B$. $B$, AtT-20 cells were analyzed for secretion during the overnight period and after two consecutive 30 min periods of basal secretion, followed by a 30 min period of stimulated secretion $\left(1 \mathrm{~mm} \mathrm{BaCl}_{2}\right)$. ACTH levels were determined by RIA for cleaved ACTH. Data are the mean \pm SD for four determinations. Similar results were obtained in two independent experiments.

percent up to three times higher than the pro-NPY biosynthetic rate in different experiments. Regardless of the level of expression, the vast majority of POMC molecules is secreted as intact unprocessed POMC, with only a small portion cleaved to glycosylated ACTH (Fig. 7B). As expected, pro-NPY is processed extensively to NPY within the cells, and NPY is the major secreted form (Marek and Mains, 1989; Paquet et al., 1996) (data not shown). The SCG neurons express POMC at high levels and process POMC very inefficiently to $\mathrm{ACTH}$; the vast majority of the POMC molecules is rapidly secreted intact from the cells. By contrast to mature NPY, cleaved mature ACTH is present in a very low levels and is stored only poorly in a stimulatable pool.

\section{Normal processing, storage, and secretion of POMC products in pituitary cells}

Viral infection with AdPOMC does not alter endogenous NPY or PAM storage and secretion in the SCG neurons significantly, but the virally encoded POMC in large part is excluded from LDCVs and remains as intact POMC. To test whether these results indicate some defect in the AdPOMC virus, we have infected primary anterior pituitary and AtT-20 corticotrope tumor cells with the AdPOMC virus (Fig. 8). There is a small amount of POMC expressed in the few corticotropes in the anterior pituitary cultures (Fig. $8 A$, left), and virtually all of the POMC is stored in the cells during the $2 \mathrm{hr}$ chase. After the anterior pituitary cells have been infected, the amount of POMC expressed is vastly increased, and the complete retention of the POMC in the cells during the chase is striking (Fig. $8 A$, right). The majority of the POMC in the virally infected cultures is found by immunostaining to be in endocrine cells other than the corticotropes, as expected (data not shown). The AtT-20 cell line also was used to test the AdPOMC virus; POMC is endogenously expressed and processed to ACTH in this neuroendocrine cell line, and ACTH is stored and secreted from the LDCVs on stimulation (Fig. $8 B$, left) (Ratovitski et al., 1999). Under basal conditions, POMCinfected AtT-20 cells secrete three to four times as much immunoreactive ACTH as the noninfected cells (Fig. 8B, right). Secretion of ACTH from POMC-infected cells is stimulated three- to fourfold, as observed for noninfected AtT-20 cells (as shown before) (Ratovitski et al., 1999). In contrast to the SCG neurons, virally encoded POMC is processed, stored, and secreted as efficiently from the pituitary LDCVs as is the endogenous POMC. Thus, expressing more POMC molecules does not prevent pituitary cells from processing, storing, and releasing the exogenous POMC in the same manner as the endogenous POMC. Similarly, efficient processing and storage of exogenous POMC were seen, using stably transfected AtT-20 cells (Noel et al., 1991).

\section{Overexpressed PAM-1 is not processed in SCG neurons}

POMC normally is not expressed in the SCG neurons; hence its failure to undergo effective cleavage and storage might reflect this fact. To study the expression of a virally derived protein that is identical to an endogenous SCG protein, we have overexpressed PAM-1 by using recombinant adenovirus (AdPAM-1) and studied how the SCG neurons process, store, and secrete the additional PAM-1. Western blot analysis of the medium and cell extract samples shows higher levels of intact PAM-1 within the cell extracts of PAM-1-infected neurons as compared with cell extracts from noninfected cells (Fig. 9A, asterisk). No increase in the level of the smaller, cleaved PAM proteins is observed. PHM activity detected in cell extracts from PAM-1-infected cells is several-fold higher than in cell extracts from noninfected cells (Fig. 9B).

Surprisingly, no changes in the levels of PAM-1 processed products are detected in either basal or stimulated medium samples (Fig. 9A). PHM enzyme activity measured in medium col- 
A.

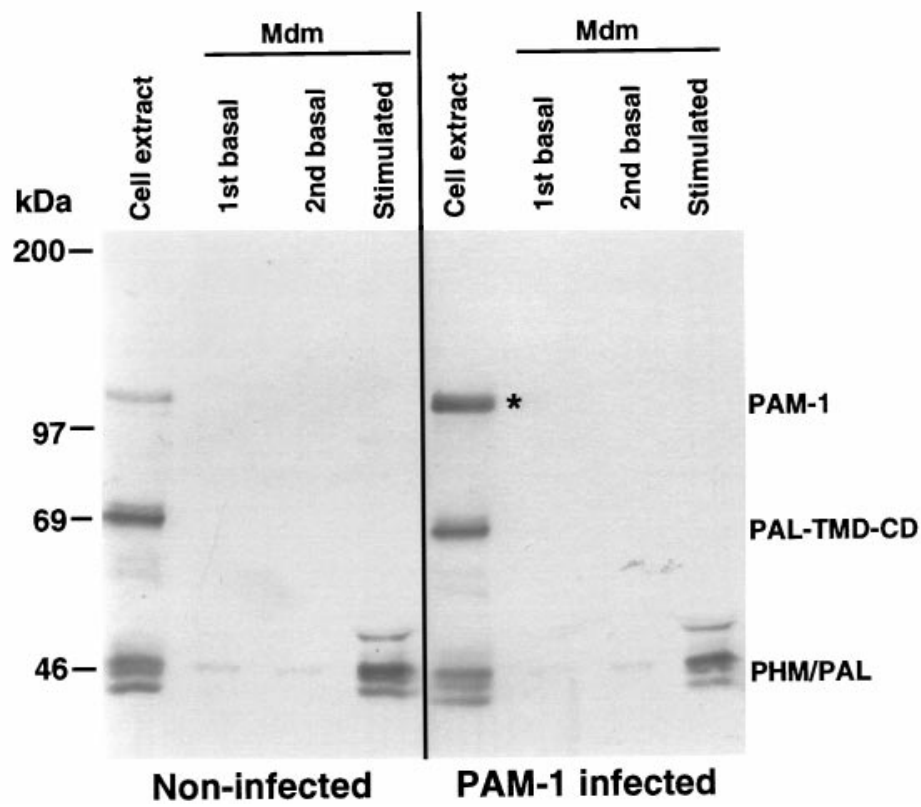

B.

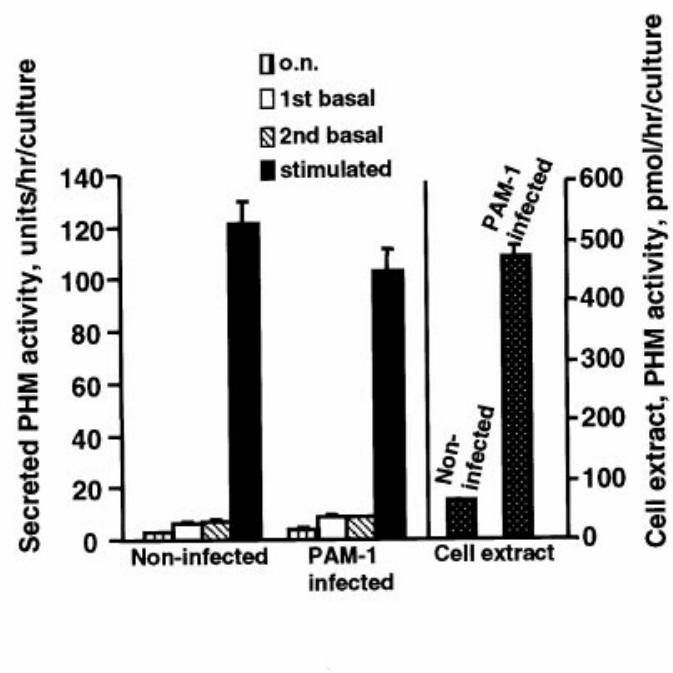

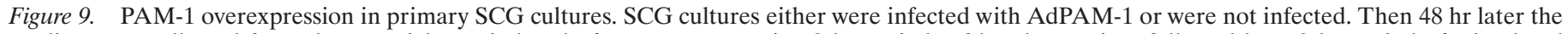

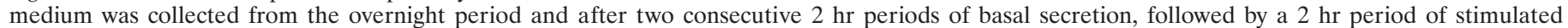

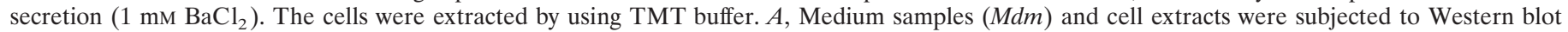

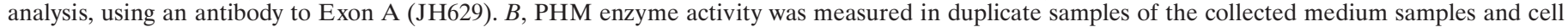
extracts. Similar results were obtained in three independent experiments.

lections is in agreement with the Western blot results (Fig. 9A,B). Thus overexpression of virally derived PAM-1 in the SCG neurons results in much higher levels of PAM-1 protein within the cell without more processing and secretion of PAM proteins, as compared with noninfected cells. The lack of cleavage of overexpressed PAM-1 in the SCG neurons is consistent with the very limited processing of POMC to ACTH.

\section{Virally derived PAM-1 is processed and stored in AtT-20 cells}

As an additional control for the application of the adenovirus system to study protein expression, we have infected AtT-20 cells with the AdPAM-1 virus and compared virally infected AtT-20 cells with PAM-1 stable cell lines. PAM protein is expressed endogenously in AtT-20 cells at low levels that are readily detectable by using the enzymatic assays for both PHM and PAL but that are undetectable by using standard immunostaining conditions (Mains and Eipper, 1984; Milgram et al., 1992). As observed via immunostaining (Fig. $10 \mathrm{~A}$ ), virally derived PAM-1 is localized in the perinuclear region (TGN area) and at the tips of cellular processes (where the LDCVs are located), as previously shown for stably transfected PAM-1 (Milgram et al., 1992, 1997).

Virally derived PAM-1 is cleaved and stored in the AtT-20 LDCVs (Fig. 10B), and up to 10 -fold more PHM activity is present in cell extracts from PAM-1-infected cells as compared with noninfected AtT-20 cells (Fig. 10C). Furthermore, several TMD-CD fragments are detected in the PAM-1-infected cell extracts (see \#, Fig. 10B, PAM-CD Ab). Western blot analyses of the basal medium collections reveal the release of a bifunctional PHM/PAL fragment (Fig. 10B, asterisk) and the monof unctional PHM domain (Fig. 10B, arrow) by PAM-1-infected cells. Secretion of the PHM domain is stimulated threefold in response to $\mathrm{BaCl}_{2}$ (Fig. $10 \mathrm{~B}$, arrow); the level of PAM expression in these experiments was maintained below the level that interferes with stimulated secretion (Ciccotosto et al., 1999). None of the PAM isoforms is detectable in basal medium collections from noninfected cells, whereas a faint doublet of PHM is observed in the stimulated medium sample. A fraction of the virally derived PAM is cleaved near the transmembrane domain and constitutively secreted as a bifunctional PHM/PAL molecule; similar cleavages are seen in fibroblasts expressing PAM-1 (Yun and Eipper, 1995).

\section{DISCUSSION}

The bifunctional enzyme PAM post-translationally modifies approximately one-half of all mammalian neuropeptides by converting a $\mathrm{COOH}$-terminal glycine into an essential $\alpha$-amide group (Eipper et al., 1992). This modification is critical to the bioactivity of the neuropeptides and hormones, occurring primarily in immature secretory granules. Therefore, PAM is an excellent marker for the peptidergic phenotype, and these data demonstrate that the SCG metabolism of PAM is not identical to the pituitary metabolism of PAM. Specifically, although the level of PAM in SCG is comparable to the very high level of PAM in anterior pituitary, the PAM-1-processing pattern in the SCG neurons is quite different from that obtained with pituitary, where the PHM domain is released from the integral membrane PAM-1 and the PAL domain is retained bound to the membrane. Monofunctional PHM and PAL domains of PAM are secreted from cultured SCG neurons, whereas no bifunctional form of PAM is secreted; both domains are cleaved from the initial integral membrane PAM-1. This is consistent with the expression of PC2 in the SCG neurons (Paquet et al., 1996), and PC2 apparently cleaves both in Exon A and after the PAL domain, whereas the anterior pituitary and AtT-20 have only PC1 and perform the cleavage only within Exon A (Bloomquist et al., 1991). It is interesting that 


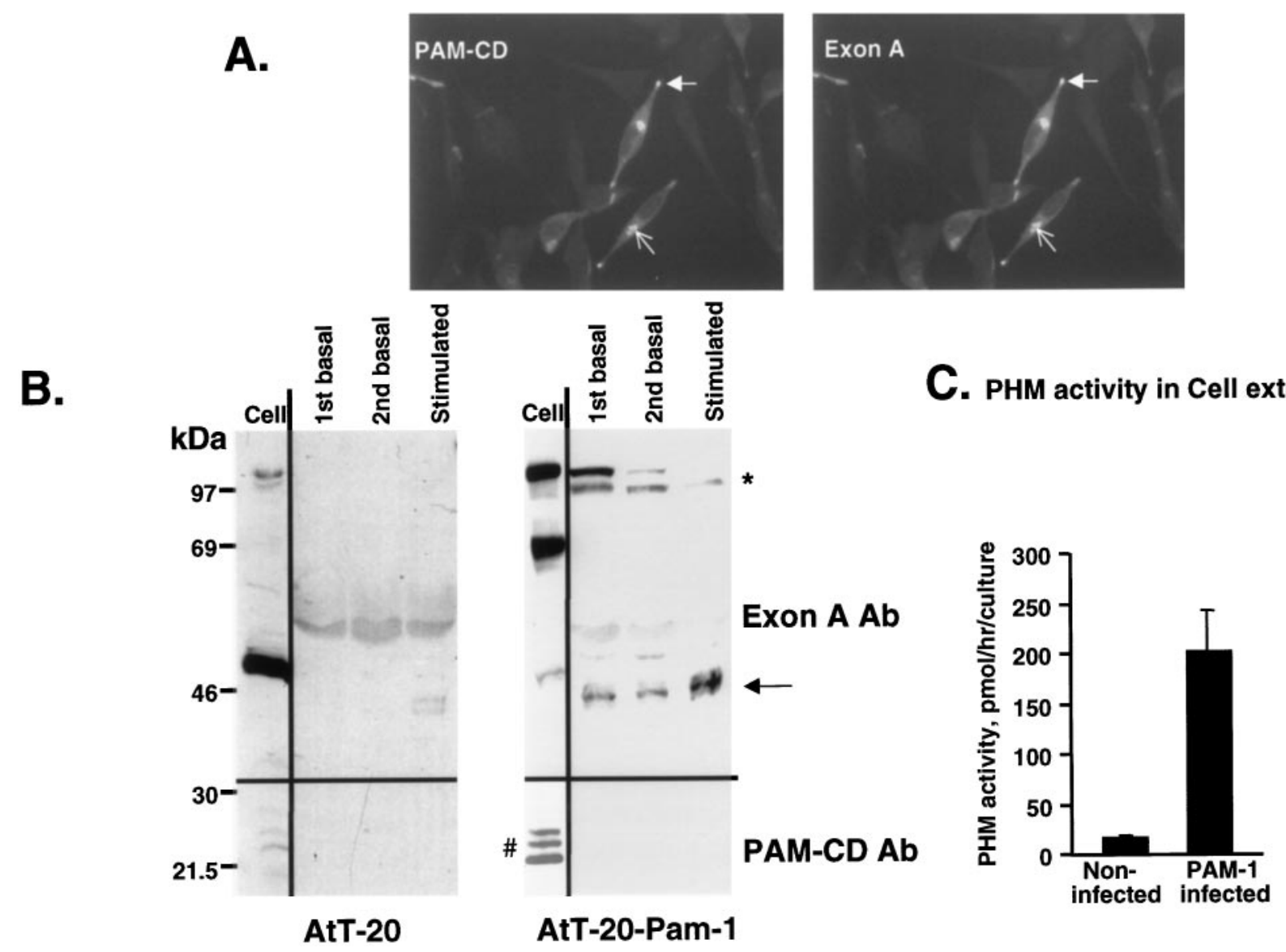

Figure 10. PAM-1 overexpression in AtT-20 cells. A, AtT-20 cells were infected with the AdPAM-1 virus. Then 48 hr later the cells were fixed and permeabilized. Cells were incubated simultaneously with polyclonal antibody to Exon A (JH629) and monoclonal antibody to PAM-CD (6E6). AtT-20 cells either were infected with AdPAM-1 or were not infected. The medium was collected $48 \mathrm{hr}$ later from the overnight period and after two consecutive 30 min periods of basal secretion, followed by a $30 \mathrm{~min}$ period of stimulated secretion $\left(1 \mathrm{mM} \mathrm{BaCl} \mathrm{Ba}_{2}\right)$. Cells were extracted by using TMT buffer. $B$, Medium samples and cell extracts were subjected to Western blot analysis, using an antibody to Exon A (JH629, top) and an antibody to PAM-CD (mAb $6 \mathrm{E} 6$, bottom). $C$, PHM activity was measured in duplicate samples of cell extracts. Similar results were obtained in two independent experiments.

the soluble PAL purified from bovine samples was from neurointermediate pituitary extracts, and both the intermediate and neural lobes of the pituitary contained abundant PC2 (Bloomquist et al., 1991; Day et al., 1992; Eipper et al., 1993).

Immunostaining indicates that PAM proteins reside in punctate vesicle-like structures distributed throughout the perinuclear area and axons in a similar way to NPY. In addition, secretion studies show that the cleaved PAM-derived products (PHM and PAL) and NPY are stored in highly stimulatable granules. For both PAM and NPY the storage is also extremely efficient, with basal secretion rates $\sim 0.5-1 \%$ of the cellular content per hour and with a 10 - to 20 -fold stimulation of the rate of secretion in response to secretagogue. These data demonstrate that PAM proteins in the SCG neurons are stored in the LDCVs with NPY.

The mechanisms involved in the processing and trafficking of proteins into the LDCVs in highly polarized cells, such as SCG neurons, are not fully understood. Recent advances in neuronal gene transfer by viral infection have made it possible to deliver foreign genes with high efficiency and low toxicity and, therefore, to study different aspects of neuronal cell biology (Kochanek et al., 1996; Moriyoshi et al., 1996; Paquet et al., 1996; Slack and Miller, 1996; Marx and Mains, 1997; Pahl and Baeuerle, 1997; Johns et al., 1999). We have used the adenoviral system to overexpress POMC and PAM-1. POMC has been expressed at various levels in the SCG neurons, from a few percent of the endogenous NPY level up to three times the level of NPY, and punctate immunostaining of ACTH is seen in axons. However, regardless of the level of expression, quantitative studies reveal that the majority of the POMC molecules is secreted constitutively without cleavage, whereas only a small percentage of the POMC molecules is processed to ACTH and secreted through the regulated LDCVs. These POMC results seem extremely puzzling in the context of continued excellent cleavage, storage, and stimulation of secretion for the endogenous NPY and PAM by the same neurons. Thus the exogenous POMC and the endogenous NPY and PAM are handled quite differently by the SCG neurons.

One possible explanation of these results might have been significant non-neuronal cell contamination of the SCG neuron cultures, because non-neuronal cells would not be expected to cleave or store POMC. However, non-neuronal cells are not present, based on phase-contrast microscopy and visualization with FITC-phalloidin, which shows brilliant illumination of the actin fiber bundles in non-neuronal cells. Less than $5 \%$ of the cells in the culture were non-neuronal, ruling out this explanation of the data. In addition, immunostaining with antibody to POMC in cultures infected with the POMC virus uncovered no nonneuronal cells. Adenovirus-mediated damage to the ability of the 
SCG neurons to process, store, and secrete peptides and proteins could explain the inability of adenovirally encoded POMC to undergo cleavage and storage in SCG neurons. However, the ability of the neurons to process, store, and secrete endogenous NPY and PAM essentially was unaltered by the viral treatments. A defect in the adenoviral POMC construction was ruled out because adenoviral POMC is processed, stored, and secreted normally in AtT-20 cells, which express and process POMC endogenously, and also is stored extremely efficiently by primary anterior pituitary cells.

Data from endocrine cells suggest that precursors are stored less efficiently than cleaved products (Naggert et al., 1995; Furuta et al., 1997; Arvan and Castle, 1998). If this were the explanation for the POMC data, the lack of storage simply might reflect the fact that neurons cannot cleave POMC. The initial cleavage of POMC usually is mediated by PC1 in cells that make POMC endogenously, and SCG neurons lack PC1 (Zhou et al., 1993). However, anterior pituitary cells store adenovirally encoded POMC extremely efficiently and cleave only a small fraction of the added POMC.

To test whether the SCG neurons discriminate against the exogenous POMC in favor of the endogenous NPY, we introduced a product endogenous to the neurons (PAM-1), using the adenoviral system. Although the introduction of adenovirally encoded PAM-1 resulted in graded increases in the SCG content of intact PAM-1, no increase in PAM-derived cleaved products (soluble PHM and PAL) was observed in cell extracts or in spent medium. That the PAM-1 virus is defective was ruled out by using AtT-20 cells, which process and store the adenoviral PAM-1 in a manner identical to PAM-1 expressed by inducible cell lines, as well as by cell lines stably expressing PAM-1 (Ciccotosto et al., 1999). In addition, the adenoviral PAM-1 has been introduced into primary anterior pituitary cultures and was cleaved and stored very efficiently, along with the initially high level of endogenous PAM-1 and PAM-derived products in anterior pituitary (R. El Meskini and B. Eipper, unpublished observations).

It is clear from these data that the expression of POMC and PAM-1 is cell type-specific: neither AtT-20 nor primary anterior pituitary endocrine cells show a pattern of discrimination against exogenous proteins as reported here for SCG neurons. It is possible that the viral mRNAs, which are shorter than the endogenous mRNAs and deliberately lack potential elements controlling expression in the $5^{\prime}$ and $3^{\prime}$ untranslated regions, are missing essential information targeting them to certain zones within the cell; therefore, the proteins do not enter the proper Golgi area that allow them to be targeted to the LDCVs (Hegde and Lingappa, 1999; Martone et al., 1999; Mohr, 1999). However, viral constructs limited to the protein-coding region yield functional inwardly rectifying potassium channels targeted normally to the membranes of dendrites and axons of SCG neurons (Johns et al., 1999). The targeting of mRNAs in cells is known to be dependent, at least in part, on small stretches of nucleotides in untranslated regions (Ainger et al., 1997; Martone et al., 1999). There is substantial evidence that the endoplasmic reticulum is heterogeneous, that the Golgi is also very heterogeneous, and that groups of proteins destined to one final site may be grouped together early in the secretory pathway (Chanat et al., 1997; Rodriguez de Turco et al., 1997; Urbe et al., 1997; Dannies, 1999; Hegde and Lingappa, 1999; Ladinsky et al., 1999). Similar to the overexpression of PAM-1, recombinant GABA $_{\mathrm{B}}$ receptors fail to be targeted to the neuronal membrane, although those receptors are expressed endogenously by the SCG neurons (Couve et al., 1998).
One plausible explanation is that the capacity of the LDCVs is selective and limited, and, therefore, no more peptides or proteins can be stored in the neuronal granules; this is quite surprising, given the plasticity of sympathetic neurons with respect to neurotransmitter phenotype (Fann and Patterson, 1998; Francis and Landis, 1999; Groves and Bronner-Fraser, 1999). The PHMspecific activity in the SCG neurons is very high (higher than the levels in anterior pituitary and atrium and comparable to the level of PHM in the most extreme tumors) (Mueller et al., 1993; Scopsi et al., 1998). It is also possible that the targeting of more PAM-1, which is membrane-bound, is limited by accessory protein or proteins that are involved in PAM trafficking (Kalirin-like; P-CIP2) (Alam et al., 1996). It appears that POMC molecules are less well targeted to LDCVs than NPY; in support of this idea, overexpressed exogenous NPY was stored in AtT-20 LDCVs more efficiently than the endogenous POMC (Dickerson et al., 1987). Another possibility is that cleavage is required for the aggregation and targeting of POMC products to LDCVs, and SCG neurons lack PC1, which normally mediates POMC processing in corticotropes. However, exogenous PAM-1 is not treated identically to endogenous PAM-1 in the SCG neurons, and POMC is stored very well in anterior pituitary without being cleaved extensively, so the selectivity is quite sophisticated.

These data raise the following question: how does a cell sense the number of LDCVs it possesses and adapt to the need for more (as when expressing an exogenous protein)? Perhaps neurons need additional signals to adjust the number of LDCVs upward, whereas endocrine cells adapt more readily to an increased demand on the LDCV pool.

\section{REFERENCES}

Ainger K, Avossa D, Diana AS, Barry C, Barbarese E, Carson JH (1997) Transport and localization elements in myelin basic protein mRNA. J Cell Biol 138:1077-1087.

Alam MR, Caldwell BD, Johnson RC, Darlington DN, Mains RE, Eipper BA (1996) Novel proteins that interact with the COOH-terminal cytosolic routing determinants of an integral membrane peptideprocessing enzyme. J Biol Chem 271:28636-28640.

Arvan P, Castle JD (1998) Sorting and storage during secretory granule biogenesis: looking backward and looking forward. Biochem J 332:593-610

Bloomquist BT, Eipper BA, Mains RE (1991) Prohormone-converting enzymes: regulation and evaluation of function using antisense RNA. Mol Endocrinol 5:2014-2024.

Bornstein MB (1958) Reconstituted rat tail collagen used as a substrate for tissue cultures on coverslips in Maximow slides and roller tubes. Lab Invest 7:134-137.

Brandenburg CA, May V, Braas KM (1997) Identification of endogenous sympathetic neuron PACAP: depolarization regulates production and secretion through induction of multiple propeptide transcripts. J Neurosci 17:4045-4055.

Calakos N, Scheller RH (1996) Synaptic vesicle biogenesis, docking, and fusion; a molecular description. Physiol Rev 76:1-29.

Chanat E, Dittie AS, Tooze SA (1997) Analysis of the sorting of secretory proteins to the regulated secretory pathway: a subcellular fractionation approach. Methods Mol Biol 88:285-324.

Ciccotosto GD, Schiller MR, Eipper BA, Mains RE (1999) Induction of integral membrane PAM expression in AtT-20 cells alters the storage and trafficking of POMC and PC1. J Cell Biol 144:459-471.

Couve A, Filippov AK, Connolly CN, Bettler B, Brown DA, Moss SJ (1998) Intracellular retention of recombinant GABA-B receptors. J Biol Chem 273:26361-26367.

Dannies PS (1999) Protein hormone storage in secretory granules: mechanisms for concentration and sorting. Endocr Rev 20:3-21.

Davis SE, Munson PJ, Jaffe ML, Rodbard D (1980) Radioimmunoassay data processing with a small programmable calculator. J Immunoassay $1: 15-25$.

Day R, Schafer MK-H, Watson SJ, Chretien M, Seidah NG (1992) 
Distribution and regulation of the prohormone convertases PC1 and PC2 in the rat pituitary. Mol Endocrinol 6:485-497.

Dickerson IM, Dixon JE, Mains RE (1987) Transfected human neuropeptide Y cDNA expression in mouse pituitary cells. Inducible high expression, peptide characterization, and secretion. J Biol Chem 262:13646-13653.

Eipper BA, Mains RE, Glembotski CC (1983) Identification in pituitary tissue of a peptide $\alpha$-amidation activity that acts on glycine-extended peptides and requires molecular oxygen, copper, and ascorbic acid. Proc Natl Acad Sci USA 80:5144-5148.

Eipper BA, Stoffers DA, Mains RE (1992) The biosynthesis of neuropeptides: peptide $\alpha$-amidation. Annu Rev Neurosci 15:57-85.

Eipper BA, Milgram SL, Husten EJ, Yun H-Y, Mains RE (1993) Peptidylglycine $\alpha$-amidating monooxygenase: a multifunctional protein with catalytic, processing and routing domains. Protein Sci 2:489-497.

Fann MJ, Patterson PH (1998) Analysis of gene expression in cultured primary neurons. Curr Top Dev Biol 36:183-195.

Francis NJ, Landis SC (1999) Cellular and molecular determinants of sympathetic neuron development. Annu Rev Neurosci 22:541-566.

Freidin M, Dougherty M, Kessler JA (1993) Cell density regulates NPY expression in cultured sympathetic neurons. Brain Res 615:135-140.

Furuta M, Yano H, Zhou A, Rouille Y, Holst JJ, Carroll R, Ravazzola M, Orci L, Furuta H, Steiner DF (1997) Defective prohormone processing and altered pancreatic islet morphology in mice lacking active SPC2. Proc Natl Acad Sci USA 94:6646-6651.

Groves AK, Bronner-Fraser M (1999) Neural crest diversification. Curr Top Dev Biol 43:221-258.

Hall AK, MacPhedran SE (1995) Multiple mechanisms regulate sympathetic phenotype. Development 121:2361-2371.

Hardy S, Kitamura M, Harris-Stansil T, Dai Y, Phipps ML (1997) Construction of adenovirus vectors through Cre-lox recombination. J Virol 71:1842-1849.

Hegde RS, Lingappa VR (1999) Regulation of protein biogenesis at the endoplasmic reticulum membrane. Trends Cell Biol 9:132-137.

Hyatt-Sachs H, Schreiber RC, Bennett TA, Zigmond RE (1993) Phenotypic plasticity in adult sympathetic ganglia in vivo. J Neurosci 13:1642-1653.

Jahn R, Sudhof TC (1993) Synaptic vesicle traffic: rush hour in the nerve terminal. J Neurochem 61:12-21.

Johns DC, Marx R, Mains RE, O’Rourke B, Marban E (1999) Inducible genetic suppression of neuronal excitability. J Neurosci 19:1691-1697.

Klumperman J, Spijker S, van Minnen J, Sharp-Baker H, Smit AB, Geraerts WPM (1996) Cell type-specific sorting of neuropeptides: a mechanism to modulate peptide composition of large dense-core vesicles. J Neurosci 16:7930-7940.

Kochanek S, Clemens PR, Mitani K, Chen HH, Chan S, Caskey CT (1996) A new adenoviral vector: replacement of all viral coding sequences with $28 \mathrm{~kb}$ of DNA independently expressing both full-length dystrophin and $\beta$-galactosidase. Proc Natl Acad Sci USA 93:5731-5736.

Ladinsky MS, Mastronade DN, McIntosh JR, Howell KE, Staehelin LA (1999) Golgi structure in three dimensions: functional insights from the normal rat kidney cell. J Cell Biol 144:1135-1149.

Lundberg JM (1996) Pharmacology of cotransmission in the autonomic nervous system. Pharmacol Rev 48:113-169.

Mains RE, Eipper BA (1976) Biosynthesis of adrenocorticotropic hormone in mouse pituitary tumor cells. J Biol Chem 251:4115-4120.

Mains RE, Eipper BA (1979) Synthesis and secretion of corticotropins, melanotropins, and endorphins by rat intermediate pituitary cells. J Biol Chem 254:7885-7894.

Mains RE, Eipper BA (1984) Secretion and regulation of two biosynthetic enzyme activities, peptidyl-glycine $\alpha$-amidating monooxygenase and a carboxypeptidase, by mouse pituitary corticotropic tumor cells. Endocrinology 115:1683-1690.

Mains RE, Eipper BA (1999) Peptides. In: Basic neurochemistry, Ed 6 (Siegel GJ, Agranoff BW, Wayne Albers R, Fisher SK, Uhler MD, eds), pp 363-382. Philadelphia: Lippincott-Raven.

Mains RE, Patterson PH (1973) Primary cultures of dissociated sympathetic neurons. III. Changes in metabolism with age in culture. J Cell Biol 59:361-366.

Maltese JY, Eipper BA (1992) Developmental expression of PAM in primary cultures of neonatal rat cardiocytes. Mol Endocrinol 6:1998-2008.

Marek KL, Mains RE (1989) Biosynthesis, development, and regulation of neuropeptide Y in superior cervical ganglion culture. J Neurochem 52:1807-1816.
Marschner I, Herndl R, Scriba PC (1980) Comparison of four different algorithms for the calculation of radioimmunoassay curves. J Clin Chem Clin Biochem 18:105-109.

Martone ME, Pollock JA, Ellisman MH (1999) Subcellular localization of mRNA in neuronal cells: contributions of high-resolution in situ hybridization techniques. Mol Neurobiol 18:227-246.

Marx R, Mains RE (1997) Adenovirally encoded prohormone convertase-1 functions in atrial myocyte large dense core vesicles. Endocrinology 138:5108-5118.

May V, Braas KM (1995) PACAP regulation of sympathetic neuron NPY and catecholamine expression. J Neurochem 65:978-987.

May V, Brandenburg CA, Braas KM (1995) Differential regulation of sympathetic neuron NPY and catecholamine content and secretion. J Neurosci 15:4580-4591.

May V, Beaudet MM, Parsons RL, Hardwick JC, Gauthier EA, Durda JP, Braas KM (1998) Mechanisms of PACAP-induced depolarization of SCG neurons. Ann NY Acad Sci 865:164-175.

McGreevey LS, Seeley RJ (1999) Quantification of hypothalamic mRNA changes during fasting using phosphor imaging. Nature 397:24S-25S.

Mehler MF, Marmur R, Gross R, Mabie PC, Zang Z, Papavasiliou A, Kessler JA (1995) Cytokines regulate the cellular phenotype of developing neural lineage species. Int J Dev Neurosci 13:213-240.

Milgram SL, Johnson RC, Mains RE (1992) Expression of individual forms of peptidylglycine $\alpha$-amidating monooxygenase in AtT-20 cells: endoproteolytic processing and routing to secretory granules. J Cell Biol 117:717-728.

Milgram SL, Eipper BA, Mains RE (1994) Differential trafficking of soluble and integral membrane secretory granule-associated proteins. J Cell Biol 124:33-41.

Milgram SL, Chang EY, Mains RE (1996a) Processing and routing of a membrane-anchored form of proneuropeptide Y. Mol Endocrinol 10:837-846.

Milgram SL, Mains RE, Eipper BA (1996b) Identification of routing determinants in the cytosolic domain of a secretory granule-associated integral membrane protein. J Biol Chem 271:17526-17535.

Milgram SL, Kho ST, Martin GV, Mains RE, Eipper BA (1997) Localization of integral membrane peptidylglycine $\alpha$-amidating monooxygenase in neuroendocrine cells. J Cell Sci 110:695-706.

Mohr E (1999) Subcellular RNA compartmentalization. Prog Neurobiol 57:507-525.

Moriyoshi K, Richards LJ, Akazawa C, O’Leary DDM, Nakanishi S (1996) Labeling neural cells using adenoviral gene transfer of membrane-targeted GFP. Neuron 16:255-260.

Mueller GP, Husten EJ, Mains RE, Eipper BA (1993) Peptide $\alpha$-amidation and peptidylglycine $\alpha$-hydroxylating monooxygenase: control by disulfiram. Mol Pharmacol 44:972-980.

Naggert JK, Fricker LD, Varlamov O, Nishina PM, Rouille Y, Steiner DF, Carroll RJ, Paigen BJ, Leiter EH (1995) Hyperproinsulinemia in obese fat/fat mice associated with a carboxypeptidase E mutation which reduces enzyme activity. Nat Genet 10:135-142.

Noel G, Keutmann HT, Mains RE (1991) Investigation of the structural requirements for peptide precursor processing in AtT-20 cells using site-directed mutagenesis of proadrenocorticotropin/endorphin. Mol Endocrinol 5:404-413.

Oyarce AM, Eipper BA (1993) Neurosecretory vesicles contain soluble and membrane-associated monof unctional and bifunctional PAM proteins. J Neurochem 60:1105-1114.

Oyarce AM, Eipper BA (1995) Identification of subcellular compartments containing peptidylglycine $\alpha$-amidating monooxygenase in rat anterior pituitary. J Cell Sci 108:287-297.

Pahl HL, Baeuerle PA (1997) Endoplasmic reticulum-induced signal transduction and gene expression. Trends Cell Biol 7:50-55.

Paquet L, Massie B, Mains RE (1996) Proneuropeptide Y processing in large dense core vesicles: manipulation of prohormone convertase expression in sympathetic neurons using adenoviruses. J Neurosci 16:964-973.

Polgar E, Shehab SAS, Watt C, Todd AJ (1999) GABAergic neurons that contain neuropeptide Y selectively target cells with the neurokinin 1 receptor in laminae III and IV of the rat spinal cord. J Neurosci 19:2637-2646.

Quatacker J, Miserez B, Annaert WG, de Potter W (1993) Ultrastruc- 
tural localization of neuropeptide $\mathrm{Y}$ immunoreactivity in the axonal reticulum elements, accumulating anterogradely in transected rat sciatic nerve. Brain Res 627:249-253.

Ratovitski EA, Alam MR, Quick RA, McMillan A, Bao C, Hand TA, Johnson RC, Mains RE, Eipper BA, Lowenstein CJ (1999) Kalirin inhibition of inducible nitric oxide synthase. J Biol Chem 274:993-999.

Rodriguez de Turco EB, Deretic D, Bazan NG, Papermaster DS (1997) Post-Golgi vesicles cotransport docosahexaenoyl-phospholipids and rhodopsin during frog photoreceptor membrane biogenesis. J Biol Chem 272:10491-10497.

Schnabel E, Mains RE, Farquhar MG (1989) Proteolytic processing of pro-ACTH/endorphin begins in the Golgi complex of pituitary corticotropes and AtT-20 cells. Mol Endocrinol 3:1223-1235.

Scopsi L, Lee R, Gullo M, Collini P, Husten EJ, Eipper BA (1998) Peptidylglycine $\alpha$-amidating monooxygenase in neuroendocrine tumors-its identification, characterization, quantification, and relation to the grade of morphological differentiation, amidated peptide content, and granin histochemistry. Appl Immunohistochem 6:120-132.

Shadiack AM, Vaccariello SA, Zigmond RE (1995) Galanin expression in sympathetic ganglia after partial axotomy is highly localized to those neurons that are axotomized. Neuroscience 65:1119-1127.

Slack RS, Miller FD (1996) Viral vectors for modulating gene expression in neurons. Curr Opin Neurobiol 6:576-583.

Slack RS, Belliveau DJ, Rosenberg M, Atwal J, Lochmuller H, Aloyz R,
Haghighi A, Lach B, Seth P, Cooper E, Miller FD (1996) Adenovirusmediated gene transfer of the tumor suppressor p53 induces apoptosis in postmitotic neurons. J Cell Biol 135:1085-1096.

Tajti J, Moller S, Uddman R, Bodi I, Edvinsson L (1999) The human superior cervical ganglion: neuropeptides and peptide receptors. Neurosci Lett 263:121-124.

Tatemoto K, Carlquist M, Mutt V (1982) Neuropeptide Y, a novel brain peptide with structural similarities to peptide YY and pancreatic polypeptide. Nature 296:659-660.

Uhler M, Herbert E (1983) Complete amino acid sequence of mouse POMC derived from the nucleotide sequence of POMC cDNA. J Biol Chem 258:257-261.

Urbe S, Tooze SA, Barr FA (1997) Formation of secretory vesicles in the biosynthetic pathway. Biochim Biophys Acta 1358:6-22.

Xu Z-Q, Shi T-J, Hokfelt T (1996) Expression of galanin and a galanin receptor in several sensory systems and bone anlage of rat embryos. Proc Natl Acad Sci USA 93:14901-14905.

Yun H-Y, Eipper BA (1995) Addition of the KDEL endoplasmic reticulum signal does not block maturation of enzymatically active peptidylglycine $\alpha$-amidating monooxygenase. J Biol Chem 270:15412-15416.

Zhou A, Bloomquist BT, Mains RE (1993) The prohormone convertases PC1 and PC2 mediate distinct endoproteolytic cleavages in a strict temporal order during POMC biosynthetic processing. J Biol Chem 268:1763-1769. 